11. Tereschenko, V.K. (2010). Orhanizatsijno-ekonomichnyj mekhanizm rozvytku sil's'kykh terytorij [Organizational and Economic Mechanism for the Development of Rural Areas]. Nizhyn: Vydavets' PP Lysenko M.M. [in Ukrainian].

12. Shpychak, O.M. \& Svynous, I.V. (2008). Realizatsiia produktsii osobystymy selians'kymy hospodarstvamy - vytraty, tsiny, efektyvnist' [Realization of products by private peasant farms - costs, prices, efficiency]. Kyiv : IAE [in Ukrainian].

Tetiana Shepel, $\mathrm{PhD}$ in Economics (Candidate of Economic Sciences), postdoctoral student Bila Tserkva National Agrarian University (Ukraine)

\title{
Theoretical Foundations of the Functioning of Personal Peasant Farms
}

The purpose of the study is to develop theoretical and methodological provisions on the functioning of private peasant farms.

The production of agricultural products in individual peasant farms should be considered as a manifestation of the protective reaction of the rural community to the negative effects of institutional changes in society, the insufficient level of development of productive forces of the state, which makes it impossible to fully provide food products to the population due to high-value production and low purchasing power of the population. The use of Western standards of division into a private peasant and farm based on the large amount of income from sales, agricultural holdings and land use in the current economic conditions of Ukraine is also not feasible. We believe that in the event of their introduction, most OSGs will acquire the status of a farm, which will result in a corresponding increase in tax pressure. The evolution of the functioning of individual peasant farms proves that during the whole period of existence OSG tried to minimize their formal relations with the state. The root cause of these circumstances was an ambiguous attitude of the authorities to their activities, where the ideological beliefs and unpredictability of their activities are motivating. We consider that the category of "private peasant economy" is appropriate to be interpreted as a "private subsidiary" - a type of agricultural activity of households concentrated in villages and settlements, which has no entrepreneurial direction and is characterized by the following features: the purpose of production - self-provision of food products, with the sale of the remainder of the resulting agricultural products; in the conditions of economic stability - an element of secondary, and during periods of economic troubles - basic employment and is not the main source of the formation of the total resources of the rural household; for the production of agricultural products, the work of household members is used.

In the conditions of economic growth, the role of OSG in providing food to the population of Ukraine will be lost. In these conditions, the share of income from OSG in the structure of the total resources of the rural household will decrease, which will create conditions for their transformation into "hobby-farm". personal peasant economy, transformation, hobby-farm, agricultural products, survival

Ю. В. Гвоздєв, асп.

Білоиерківський начіональний аграрний університет, м. Біла Церква, Украӥна

\section{Економічна сутність і значення інвестицій та інвестиційної діяльності суб'сктів господарювання}

В статті розкривається економічна сутність і значення інвестиційної діяльності суб'єктів господарювання. Узагальнюючи вищезазначене, систематизуємо найбільш важливі ознаки інвестицій: дозволяють реалізувати безліч цілей - економічні (у вигляді отримання доходу), менеджменту (підвищення якості та конкурентоспроможності продукції, оптимізації витрат та ін.), неекономічні (соціальні, екологічні); сприяють перетворенню різних ресурсів господарюючих суб' єктів у альтернативні види активів; забезпечують відповідність ринковим законам попиту та пропозиції на інвестиційні ресурси та послуги; супроводжуються ризиками вкладення капіталу, тобто ймовірністю очікуваних результатів цілям інвестування; характеризуються невизначеністю термінів отримання досягнутого ефекту від здійснення інвестицій, а також залежністю термінів отримання вигод від управлінських рішень інвестора.

інвестиція, капітальні вкладення, суб'єкт господарювання, діяльність, фінансові ресурси

(C) Ю. В. Гвоздєв, 2018 
Ю. В. Гвоздев, асп.

Белоцерковский национальный аграрный университет, г. Белая Церковь, Украина

Экономическая сущность и значение инвестиций и инвестиционной деятельности субъектов хозяйствования

В статье раскрывается экономическая сущность и значение инвестиционной деятельности субъектов хозяйствования. Обобщая вышесказанное, систематизируем наиболее важные признаки инвестиций: позволяют реализовать множество целей - экономические (в виде получения дохода), менеджмента (повышение качества и конкурентоспособности продукции, оптимизации затрат и др.), Неэкономические (социальные, экологические) способствуют превращению различных ресурсов хозяйствующих субъектов в альтернативные виды активов; обеспечивают соответствие рыночным законам спроса и предложения на инвестиционные ресурсы и услуги; сопровождаются рисками вложения капитала, то есть вероятностью ожидаемых результатов целям инвестирования; характеризуются неопределенностью сроков получения достигнутого эффекта от осуществления инвестиций, а также зависимостью сроков получения выгод от управленческих решений инвестора. инвестиция, капитальные вложения, субъект хозяйствования, деятельность, финансовые ресурсы

Постановка проблеми. Перехід до ринкової економіки супроводжувався глибокою кризою інвестиційної сфери, що знайшло прояв у різкому зниженні інвестиційної привабливості та інвестиційної активності, особливо в реальному секторі економіки. Це негативно позначилося на формуванні й розвитку матеріально-технічної бази сільського господарства та інших галузей, різко знизився рівень продуктивності праці та конкурентоспроможності вітчизняної продукції.

Сформовані темпи інвестиційного розвитку в Україні не можна визнати задовільними, вітчизняне сільське господарство значно поступається за рівнем розвитку провідним країнам світу, тому без прийняття дієвих заходів державного значення подолати ситуацію неможливо.

Послаблення негативної динаміки у вітчизняному аграрному секторі економіки, iii стабілізація та забезпечення економічного зростання потребує створення відповідних умов для залучення, інвестицій у реальний сектор, формування фінансової бази інвестування виробництва за рахунок консолідації вільних фінансових ресурсів, а також ефективного управління ними відповідно до економічних і соціальних пріоритетів.

Аналіз останніх досліджень і публікацій. Питання відтворення капіталу, джерел формування інвестицій і умов їх залучення в економіку досліджуються досить широко. До найбільш відомих зарубіжних науковців, які вивчали процеси інвестування, необхідно віднести, зокрема: Г. Бірмана та С. Шмідта [1], 3. Боді, А. Кейна та Дж. Маркуса [3], Л.Дж. Гітмана та М.Д. Джонка [5], Дж.М. Кейнса [7], Б. Коласса [9], І.В. Ліпсіца та В.В. Коссова [13], К.Р. Макконелла та С.Л. Брю [14], І. Фішера [22], У.Ф. Шарпа, Г. Александара та Дж. Бейлі [23] та інших авторів. Вагомий внесок в економічну теорію засад інвестиційної діяльності, економічної оцінки ефективності інвестицій та інвестиційної привабливості зробили вітчизняні науковці: I.О. Бланк [2], О.М. Варченко [4; 10], О.А. Кириченко та С.А. Срохін [8], Д.Ф. Крисанов [10], О.С. Кузьмін, С.В. Князь, І.Й. Малий [15], О.В. Мертенс [17], Н.В. Тувакова та А.Я. Кузнєцова [11], П.А. Лайко [12], Ю.М. Нестерчук та Ю.В. Улянич [18], С.К. Реверчук [6] та багато інших.

Разом 3 тим, незважаючи на вагомі здобутки дослідників, до цих пір у визначенні самого терміну «інвестиційна діяльність» та його сутнісних ознак відсутня єдність поглядів. Так, інвестиційна діяльність підприємства розглядається як комплекс заходів і дій фізичних та юридичних осіб, які вкладають свої ресурси (у матеріальній, фінансовій або іншій майновій формі) з метою отримання прибутку [4, с. 9]; як сукупність практичних дій громадян, юридичних осіб і держави щодо реалізації інвестицій $[10$, с. 158-167]; як придбання та реалізація підприємством тих необоротних активів, а також тих фінансових інвестицій, які не $є$ складовою еквівалентів грошових коштів - 
короткострокових високоліквідних фінансових інвестицій, що вільно конвертуються в певні суми грошових коштів і характеризуються незначним ризиком зміни їх вартості [12, с. 222]; як сукупність практичних дій iї суб'єктів (інвесторів та учасників) щодо реалізації інвестицій [19, с. 43]. Відсутність єдиного концептуального бачення інвестиційної діяльності суб' єктів господарювання та, відповідно, єдиного методичного підходу, який би дозволяв би здійснювати іiі оцінку та вимір іiї рівня, здійснювати порівняння на мікро-, мезо- та макрорівнях, моделювати можливі наслідки управлінських рішень зумовили цільову спрямованість даного дослідження.

Постановка завдання. Метою статті $є$ розробка теоретичних положень щодо трактування поняття «інвестиційна діяльність» суб’єктів господарювання та методичних підходів щодо її оцінки.

Виклад основного матеріалу. Складна структура економічних процесів, різноманіття форм відносин між суб' єктами економічних відносин зумовлюють рівень активізації інвестиційної діяльності. Підвищення інвестиційної активності розглядається як пріоритетне завдання вітчизняної економіки. Водночас, сутність процесу інвестування трактується по-різному залежно від сфери спрямування й особливостей залучення інвестицій. У реальному секторі економіки основну увагу приділяють необхідності оновлення зношених основних фондів, забезпечення розширеного відтворення, освоєння нових видів продукції за рахунок власних коштів, залучення кредитів, іноземних інвестицій та інших джерел. Для фінансових інститутів інвестиційна активність передбачає активізацію фондового ринку.

Динамічний та ефективний розвиток інвестиційної діяльності є необхідною умовою стабільного функціонування й розвитку економіки. Масштаби, структура i ефективність, використання інвестицій великою мірою визначають результати господарювання на різних рівнях економічної системи, стан, перспективи розвитку та конкурентоспроможність національного господарства.

Інвестиції - відносно новий для вітчизняної економіки термін, однак, в економічній теорії та підприємницькій практиці немає такого поняття, яке б використовувалося настільки часто й водночас - неоднозначно. Ефективність використання інвестицій створює передумови для забезпечення ефективності функціонування певної економічної системи. 3 огляду на це важливим завданням науки у даній сфері постає розробка відповідних нинішнім ринковим умовам механізмів реалізації інвестиційних потреб. Особливу роль у цьому відіграє систематизація теоретичних і практичних засад інвестиційної діяльності. Розглядаючи взаємозв'язок економічного росту та інвестицій, можна виділити кілька гіпотез щодо поведінки інвесторів. Основними із них $є$ акселераційна теорія інвестицій, теорії, що грунтується на мотивах прибутку; гіпотеза про визначальну ліквідність при прийнятті інвестиційних рішень; теорії взаємозв'язку розмірів інвестицій і величини норми процента; неокласична теорія інвестицій. В акселераційній теорії визначено, що метою виробництва $є$ його зростання. При цьому випуск продукції розглядається підприємцем лише як засіб одержання прибутку. В цій теорії величина очікуваного капіталу визначається на основі досягнутого технічного рівня розвитку пропорційно показникові обсягу виробництва, очікуваного в поточному періоді, тобто очікуваного попиту. У цілому акселераційне трактування інвестиційного процесу висвітлює однобічну залежність між величинами, які розглядаються, і тому воно вичерпно не характеризує інвестиційний процес. Відомі економісти, серед яких Адам Сміт, Альфред Маршалл, Джон Кейнс, вважали, що головний мотив інвестиційної діяльності будьякого підприємства - це одержання максимального прибутку. При цьому можливість реалізації такої стратегічної мети завжди обмежена, з одного боку, витратами виробництва, з іншого - попитом на продукцію, що виробляється підприємством.

3 погляду теорії максимізації прибутку інвестиції у приватному секторі 
реалізуються тільки тоді, коли поряд з очікуваннями збільшення збуту одержують достатню величину прибутку. Отже, вихідним пунктом прийняття інвестиційних рішень $\epsilon$ прибуток. Подальшим розвитком гіпотез, що грунтуються на мотиві прибутку як головного показника інвестиційної діяльності, є гіпотеза ліквідності. У межах цієї гіпотези наявність власних коштів для можливості самофінансування капіталовкладень розглядається як необхідна передумова для інвестиційних витрат. Гіпотеза ліквідності дає змогу врахувати відмінності у використанні власного та позиченого капіталу. Величина грошових коштів, що перебувають у розпорядженні підприємця для інвестиційних цілей, за умови власного фінансування складається із збереженого для цих цілей прибутку та амортизації, а при зовнішньому фінансуванні - із кредитів i додаткової емісії акцій. Гіпотеза ліквідності виходить із того, що насамперед формуються можливості для самостійного фінансування, а рішення залучити зовнішні джерела формування власних фінансових ресурсів приймаються після того, як будуть вичерпані всі внутрішні джерела. Ця гіпотеза може дати позитивний результат, коли спостерігається ситуація сприятливого розвитку попиту та відчується необхідність у засобах для інвестиційних вкладень у зв'язку з очікуванням розширеного попиту. На основі гіпотези ліквідності неможливо зробити висновок про динаміку інвестиційної діяльності на довгостроковий період. Вона може становити інтерес при використанні інших, більш загальних теорій, як додатковий фактор, який визначає схильність до інвестування приватного сектору залежно від наявності фінансових ресурсів.

Теорія, що визначає загальні інвестиційні витрати через ринкову норму процента, пояснює взаємозв'язок обсягів виробництва та інвестиційної активності. Невід’ємною передумовою цієї теорії є необхідність ринку досконалої конкуренції. Теорія розглядає норму процента як фактор, який приводить до рівноваги бажання інвестувати та готовності зберігати. За інвестуванням стоїть попит на відповідні ресурси, за зберіганням - їх пропозиція, у той час як норма процента є така «ціна» ресурсів для інвестиції, за якого попит і пропозиція урівноважуються. При цьому капітал, за цією теорією, являє собою майбутні доходи, продисконтовані на поточний момент часу.

Некласична теорія інвестиційної поведінки господарюючих суб’єктів визначає оптимальну величину капіталу, що використовується залежно від розмірів виробництва, ціни продукту та витрат використання капіталу. За умови, що відомі чиста вартість підприємства й витрати використання капіталу, можна розрахувати оптимальну величину капіталу з урахуванням коефіцієнта його еластичності, обсягу виробництва, індексу цін. Отже, неокласична інвестиційна теорія грунтується на понятті вартості фірми. У спрощеному вигляді вартість підприємства $€$ продисконтованими на початковому моменті часу майбутніми витратами підприємства, які підприємець максимізує. Визначення оптимальної моделі поведінки суб'єктів інвестиційної поведінки є складним та багатоплановим завданням. Це рішення тісно пов'язано із моделлю економічного розвитку, із рівнем інтеграції у глобальні економічні процеси та ін. Очевидно, що інвестиції $є$ ключовим фактором економічного росту як на макроекономічному, так і на мікроекономічному рівні. Досвід багатьох країн переконує, що інвестиції виступають каталізатором економічних процесів, а ефективність їх $\epsilon$ критерієм збалансованого розвитку суб'єктів інвестиційної діяльності. При цьому ефективність інвестицій, як наслідок - темпи економічного розвитку, деякою мірою залежать від культури інвестування, національних i регіональних особливостей інвестиційного процесу. У вітчизняній науці на відміну від зарубіжної практики поняття «інвестиції» використовується не так давно.

Вивчення зарубіжної та вітчизняної теорії інвестиційної діяльності, теоретичний аналіз методів державного регулювання інвестиційного процесу дали змогу визначити коло питань, які стосуються інструментарію інвестиційного механізму. Їх можна 
узагальнити наступним чином: засоби пізнання та економічні категорії (як інструмент пізнання функціонування інвестиційного механізму та фінансового регулювання діяльності інвестиційних інститутів, а також результатів та засобів цього пізнання), що використовуються у теорії та практиці дослідження проблем удосконалення інвестиційного механізму; інститути, що здійснюють державне фінансове регулювання, що стосуються суб'єктів інвестиційної діяльності; принципи і правила, функції, завдання та види їх виробничої діяльності; методи та важелі інвестиційного механізму, які використовуються у процесі державного (адміністративного) та ринкового (економічного) регулювання діяльності інвестиційних інститутів. Категорія як широке поняття відображає найбільш загальні та важливі властивості, ознаки, зв'язки та відносини предметів, явищ, процесів і т.д. Категорія, як писав К. Маркс, «це - важливе типове у численних тлумаченнях сутності». Щодо економічних категорій, то вони являють собою «теоретичний вираз, абстракції суспільних відносин виробництва» [16, c. 161].

Економічні категорії - важливі поняття економічної науки, які відображають істотні сторони економічних процесів та явищ (наприклад, вартість, ціна, процент, податкова ставка, прибуток, економічні нормативи регулювання діяльності, накопичення і т.д.). В Україні законодавчо визначено основні поняття та категорії інвестиційної діяльності. Так, у Законі України «Про інвестиційну діяльність» під інвестиціями розуміють усі види майнових та інтелектуальних цінностей, що вкладаються в об'єкти підприємницької та інших видів діяльності, у результаті яких утворюється прибуток або досягається соціальний ефект» [20, с. 646]. Зазначимо, якщо раніше інвестиції розглядали як «капіталовкладення», то нині активно використовується поняття «інвестиції», що охоплює ширше коло економічних відносин, які необхідно охарактеризувати.

Наукове тлумачення сутності інвестицій започаткували представники класичної школи. Так, Б. Коласс стверджував, що будь-який капітал, й особливо, будь-яке прирощення, є результатом заощадження [9, с. 345]. Виробництво продукції забезпечує певну суму грошового доходу, але завдяки заощадженню він повністю не витрачається. Грошовий ринок встановлює рівноважну ціну на використання грошей - рівноважну ставку процента, за якої обсяг заощаджених (запропонованих) грошей дорівнює обсягу інвестованих грошей (на які пред’явлено попит). Тому заощадження фактично не зумовлюють дисбалансу у потоці доходи-витрати, або рівноважна процентна ставка сприяє тому, що кожна заощаджена одиниця, потрапляючи в руки інвесторів, витрачається ними на виробниче інвестування.

Очевидним є і те, що у предметному покажчику до повного зібрання творів К. Маркса не наведено термін «інвестиції», оскільки вони не є основним предметом його досліджень. Однак, на нашу думку, праці Маркса містять деяку систему поглядів, які дозволяють визначити основні підходи і напрями аналізу інвестиційного процесу як на макро-, так і на макрорівні, що дає можливість розглядати його роботи як наступний етап у науковому осмисленні інвестиційного процесу та категорії інвестицій. На думку Маркса, гроші $є$ необхідною передумовою виникнення капіталу. Виходячи із відомої формули Г-Т-Г' саме прирощення грошей $(Г)$ у гроші $\left(\Gamma^{\prime}\right)$ через створення доданої вартості і є прирощенням вартості в капітал. Отже, використання доданої вартості як капіталу $є$ зворотним прирощенням доданої вартості у капітал, яке називається накопиченням капіталу [16, с. 592]. Накопичення капіталу відбувається лише у формі реальних інвестицій, оскільки воно забезпечує розширене відтворення і являє собою придбання або створення нових засобів виробництва. Саме тому вважаємо можливим досліджене Марксом поняття «накопичення» відносити і до поняття «інвестиції», розглядаючи їх реальну складову. Спираючись на власну концепцію капіталу і вартості, К. Маркс фактично сформував основи категорії зайнятості, на основі якої можна 
передбачити, що головним фактором, який визначає рівень зайнятості у країні, є рівень накопичення капіталу, що в нашому розумінні рівнозначно рівню реальних інвестицій. Рівновага настає тоді, коли загальна величина неоплаченої праці найманих працівників повною мірою гарантує збалансований ріст усього капіталу.

Сучасне розуміння механізму управління інвестиціями як економічної категорії сформувалося під впливом праці Дж. М. Кейнса «Загальна теорія зайнятості, процента та грошей» [7, с. 224]. Основою кейнсіанського вчення став висновок про те, що для розвитку економіки важливим є попит, який забезпечує реалізацію товарів, а не пропозиція ресурсів. Об'єднуючи закономірності впливу процентної ставки на рівень планових інвестицій i планових інвестицій на рівень національного доходу, кейнсіанська теорія виводить взаємну залежність між ставкою процента і національним доходом. Сутність «передавального механізму» Кейнса є наступною: від пропозиції грошей (M) до ставки процента (г), далі до інвестицій (I) і потім до національного доходу (Y), тобто це означає, що експансіоністська грошово-кредитна політика призводить до меншого рівня процентних ставок i вищого рівня рівноваги національного доходу. I навпаки, грошово-кредитна політика, яка скорочує грошову масу в обігу, підвищує рівноважну норму процента та знижує рівень національного доходу.

Кейнсіанській економічній політиці протистоїть монетарна теорія національного доходу i циклу, що грунтується на статистичних дослідженнях i теоретичних узагальненнях американського економіста М. Фрідмана [24, с. 25]. В основі інвестицій прибічники монетарної концепції висунули на передній план грошовий фактор. Вирішальне значення вони надають відмінностями між грошовим попитом i пропозицією. На противагу теорії Кейнса, у якого функція попиту на гроші (перевага ліквідності) є нестійкою і зазнає впливу спекулятивних факторів, у монетарній теорії функція попиту на гроші стабільна і визначається стійкою схильністю до заощадження 3 метою досягнення бажаного рівня багатства. Звідси можна зробити такий висновок: стабільність функції попиту на гроші означає, що економіка потребує стійкого збільшення грошової маси, необхідної для нормального функціонування господарства. Отже, аналіз підходів до дефініції терміна «інвестиції» у зарубіжній економічній літературі свідчить, що у різних школах і напрямах економічної думки визначення поняття «інвестиції» містять спільну рису - зв'язок інвестицій з одержанням доходу як цільової установки інвестора.

Зазначимо, що інвестиції ототожнювалися із поняттям «капітальні вкладення» і розглядалися у двох площинах: як процес, який відображає рух вартості при відтворенні основних фондів, і як економічна категорія, яка описує рух вартості, авансованої в основні фонди від моменту мобілізації грошових коштів до моменту їх відшкодування. У вітчизняній економічній літературі до 80-х років XX ст. термін «інвестиції» для аналізу процесів відтворення практично не використовували, основною сферою його застосування були перекладені праці зарубіжних авторів i дослідження у сфері капіталістичної економіки. Базовим поняттям інвестиційної діяльності $є$ поняття капітальних вкладень, однак термін «капіталовкладення» трактується вужче, ніж «інвестиції». Щодо тлумачення поняття «інвестиції», його фінансового аспекту, в середовищі вітчизняних економістів дискусія велася між прибічниками витратного i ресурсного підходів. У межах витратного підходу капітальні вкладення розглядалися як витрати на відтворення основних фондів, їх нарощення й удосконалення [17, с. 12]. За ресурсним підходом капіталовкладення - це фінансові ресурси, які витрачаються на будівництво нових, реконструкцію, розширення i технічне переозброєння діючих підприємств (виробничі та невиробничі капіталовкладення) [11, с. 41]. На нашу думку, обидві позиції не є суперечливими, а відображають зміст і форму одного й того ж явища - капітальні вкладення, яке за 
економічним змістом $є$ частиною суспільного продукту, що направляється на відтворення основних засобів, а за формою вони виступають у вигляді грошових коштів, які направляються на капітальне будівництво, придбання обладнання, машин та іншої техніки, що входить до складу основних фондів. Однак, обидва підходи мали істотний недолік, оскільки передбачав статичну характеристику об'єкта аналізу, яка базувалася на виділенні якого-небудь одного елементу інвестицій, витрат або ресурсів, що обмежувало можливості дослідження інвестицій як цілісного процесу.

Сформований досвід функціонування ринкової економіки у розвинених країнах дозволив зарубіжним науковцям сформувати теоретичні засади інвестування, однак тенденції останніх років, глобалізація, розвиток науково-технічного прогресу, світова фінансово-економічна криза, формування нової економічної парадигми зумовлюють зміни підходів до розуміння інвестицій. Очевидно, що у найближчій перспективі розуміння інвестицій буде наповнено новим економічним змістом.

Традиційно під інвестиціями прийнято розуміти здійснення певних економічних проектів сьогодні із розрахунком отримати доходи в майбутньому. Водночас, у науковій літературі немає однозначного підходу до визначення даного терміну. Так, у сучасному економічному словнику інвестиції визначено як довгострокові вкладення державного або приватного капіталу у власній країні чи за кордоном 3 метою отримання доходу в підприємствах різних галузей, підприємницькі проекти, соціальноекономічні програми, інноваційні проекти [21, с. 142]. Основоположним моментом у даному випадку є збільшення вартості об'єкта інвестицій, але інвестиції не завжди здійснюються для отримання, чітко вираженого в грошових коштах приросту вартості об'єкта капіталовкладення. Хоча отримання додаткового корисного ефекту має неодмінно бути присутнім в інвестиціях або в активному чи пасивному стані, інакше втрачається їхній зміст.

У своїй книзі «ннестиції» Вільям Ф. Шарп визначає інвестицій як вкладення грошових коштів сьогодні, щоб отримати більшу їх суму в майбутньому, при цьому автор вказує на постійний зв' язок інвестування із часом і ризиком [23, с. 235].

Відомий економіст-теоретик Дж. Кейнс розглядав інвестиції як поточний приріст цінності капітального майна в результаті виробничої діяльності певного періоду, що $є$ тією частиною доходу за цей період, яка не була використана на споживання. На думку П. Самуельсона інвестиції формуються внаслідок відмови від використання доходів на поточне споживання на користь капіталоутворення (вкладення) й очікуваного розширення споживання в майбутньому [8, с. 46]. Подібну позицію відстоюють Г. Бірман і С. Шмідт, які під інвестиціями розглядають витрати ресурсів із надією на отримання доходів у майбутньому, по закінченні достатньо тривалого періоду часу; Е. Боді, А. Кейн, А. Дж. Маркус - як витрачання наявних у певний момент ресурсів в очікуванні отримання більшого їх обсягу в майбутньому [3, с. 12]; Л. Дж. Гітман, М. Д. Джонк - як спосіб розміщення капіталу, який повинен забезпечити збереження чи зростання вартості капіталу та(чи) принести позитивну величину доходу [5, с. 13]. Отже, традиційно під інвестиціями прийнято розуміти здійснення певних економічних проектів у поточний момент часу із розрахунком отримати доходи в майбутньому. Такий підхід до розуміння інвестицій $\epsilon$ переважаючим як у вітчизняній, так і зарубіжній економічній літературі.

У більш широкому трактуванні інвестиції являють собою вкладення капіталу 3 метою подальшого його збільшення. При цьому приріст капіталу повинен бути достатнім для того, щоб компенсувати інвестору відмову від використання наявних коштів на споживання у поточному періоді, забезпечити йому винагороду за ризик та відшкодувати втрати від інфляції в майбутньому періоді. Інвестування має здійснюватися в ефективних формах, оскільки вкладення коштів у морально застарілі засоби виробництва чи технології не матиме позитивного економічного ефекту. 
Інвестиції без інновацій $є$ не раціональними, оскільки відтворення обладнання, застарілого за своїми характеристиками, є неефективним [18, с. 112].

Об’ єктами вкладення, на думку К. Р. Макконела, С. Л. Брю, можуть виступати матеріальні та фінансові активи [14, с. 288]. Американські економісти С. Фішер, Р. Дорнбуш, Р. Шмалензі [22, с. 16] розглядають інвестиційні витрати як витрати на створення нових потужностей 3 виробництва машин, фінансування житлового, промислового та сільськогосподарського будівництва, а також товарних запасів.

Більш широке трактування інвестицій було представлено позицією, згідно 3 якою інвестиції виступають як вкладення не тільки в основні фонди, а й у приріст оборотних коштів [2, с. 17]. Включення витрат на формування приросту оборотних коштів до складу капітальних витрат поклало початок дослідженню обороту інвестицій та його окремих стадій. Водночас, інвестиції, як правило, розглядалися у зв’язку 3 розширеним відтворенням основних фондів, оскільки завершення інвестиційного циклу пов’ язувалося із введенням у дію основних фондів і виробничих потужностей.

У вітчизняній економічній літературі виділяють такі підходи до дефініції поняття «інвестиції»: всі види майнових та інтелектуальних цінностей, що вкладаються в об'єкти підприємницької діяльності 3 метою отримання прибутку [13, с. 201]; вкладення капіталу в усіх його формах у різні об’єкти (інструменти) господарської діяльності з метою отримання прибутку, а також досягнення іншого економічного та неекономічного ефекту, здійснення якого базується на ринкових принципах і пов'язано з факторами часу, ризику та ліквідності [3, с. 117]; на думку фінансистів, інвестиції - це всі види активів (коштів), що вкладаються в господарську діяльність 3 метою отримання доходу, а з погляду економістів, інвестиції - це видатки на створення, розширення, реконструкцію та технічне переозброєння основного капіталу, а також не пов'язані з цим зміни оборотного капіталу, оскільки зміни у товарно-виробничих запасах здебільшого залежать від руху видатків на основний капітал [6, с. 85]; інвестиції - це значна кількість вкладень капіталу практично в усі види діяльності прибуткового характеру, а також у підприємницьку діяльність, де досягається соціальний ефект $[15$, с. 21$]$.

Висновки та перспективи подальших досліджень. Узагальнюючи вищезазначене, систематизуємо найбільш важливі ознаки інвестицій: дозволяють реалізувати безліч цілей - економічні (у вигляді отримання доходу), менеджменту (підвищення якості та конкурентоспроможності продукції, оптимізації витрат та ін.), неекономічні (соціальні, екологічні); сприяють перетворенню різних ресурсів господарюючих суб' єктів у альтернативні види активів; забезпечують відповідність ринковим законам попиту та пропозиції на інвестиційні ресурси та послуги; супроводжуються ризиками вкладення капіталу, тобто ймовірністю очікуваних результатів цілям інвестування; характеризуються невизначеністю термінів отримання досягнутого ефекту від здійснення інвестицій, а також залежністю термінів отримання вигод від управлінських рішень інвестора.

На основі перелічених властивостей інвестицій можна зазначити, що це цілеспрямоване вкладення капіталу, яке не пов'язане із поточним споживанням та передбачає перетворення ресурсів господарюючих суб'єктів із однієї форми в іншу 3 метою отримання прибутку, а також для досягнення іншого економічного та неекономічного довгострокового ефекту.

Можна виділити такі функції інвестицій відповідно до їх економічної природи: відтворення основних та оборотних коштів; трансформація капіталу для отримання кращого ефекту його власниками; підвищення виробничого потенціалу суб'єктів господарювання, що формують передумови до його зростання.

Отже, розглядаючи теоретичні основи інвестицій та інвестиційної діяльності, можна зробити висновок про те, що в сучасних умовах будь-який вид інвестицій, у тому 
числі і в агропромисловому комплексі, базується на інвестиційній діяльності, у повній відповідності з її умовами, цілями і завданнями. Окрім того, будь-які інвестиції, зокрема і в аграрному секторі, починаються із формування ефективної інвестиційної інфраструктури, яка в свою чергу в сукупності з нормативно-правовою базою більшою мірою забезпечують сприятливий інвестиційний клімат. Інвестиційна інфраструктура та інвестиційний клімат знаходяться в органічній єдності в області практичної діяльності в межах забезпечення інвестиційної діяльності.

Перспективами подальших досліджень $є$ поглиблене вивчення сутнісних характеристик та ознак інвестиційної діяльності суб' єктів господарювання різних галузей економіки з метою розробки методичних підходів щодо іiі оцінювання з урахуванням специфіки діяльності.

\section{Список літератури}

1. Бирман Г. Экономический анализ инвестиционных проектов [Текст] / Г. Бирман, С. Шмидт. - М.: ЮНИТИ, 1997. - 631 с.

2. Бланк И. А. Основы инвестиционного менеджмента: в 2 т. [Текст] / И. А. Бланк. - К.: Эльга-Н, 2001. - T. 2. -512 c.

3. Боди 3. Принципы инвестиций [Текст] / 3. Боди, А. Кейн, Дж. Маркус. - М.: Вильямс, 2002. - 984 c.

4. Варченко О. М. Бюджетна підтримка як інструмент забезпечення ефективності державної аграрної політики [Текст] / О. М. Варченко // Економіка та управління АПК. - 2012. - Вип. 9. - С. 5-9.

5. Гитман Л. Дж. Основы инвестированя [Текст] / Л. Дж. Гитман, М. Д. Джонк. - М.: Дело, 1997. $1008 \mathrm{c}$.

6. Інвестологія: наука про інвестування [Текст] : навч. посіб. / [С. К. Реверчук, Н. Й. Реверчук, І. Г. Скоморович та ін.] ; за ред. С. К. Реверчука. - К.: Атака, 2001. - 264 с.

7. Кейнс Дж. М. Общая теория занятости, процента и денег: избранные произведения [Текст] / Дж. М. Кейнс. - М.: Экономика, 1993. - С. 224-518.

8. Кириченко О. А. Інвестування [Текст] : підруч. / О. А. Кириченко, С. А. Єрохін. - К.: Знання, 2009. $-573 \mathrm{c}$.

9. Коласс Б. Управление финансовой деятельностью предприятия. Проблемы, концепции и методы [Текст] : учеб. пособ. / Б. Коласс. - М.: Финансы; ЮНИТИ, 1997. - 576 с.

10. Крисанов Д. Ф. Інвестиційно-інноваційне забезпечення продовольчого комплексу України [Текст] / Д. Ф. Крисанов, О. М. Варченко // Актуальні проблеми розвитку економіки регіону. - 2014. Вип. 10(1). - С. 156-167.

11. Кузьмін О. Є. Інвестиційна та інноваційна діяльність [Текст] : монографія / О. Є. Кузьмін, С. В. Князь, Н. В. Тувакова, А. Я. Кузнєцова. - Львів: ЛБІНБУ, 2003. - 233 с.

12. Лайко О. І. Трансформація концепції дослідження інвестиційних процесів [Текст] / О. І. Лайко // Вісник соціально-економічних досліджень. - 2013. - Вип. 1. - С. 220-229.

13. Липсиц И. В. Инвестиционній проект [Текст] : учеб. пособ. / И. В. Липсиц, В. В. Коссов. - М.: БЕК, 1996. $-528 \mathrm{c}$.

14. Макконепл К. Р. Экономикс: принципы, проблемы и политика: в 2-х томах [Текст] / К. Р. Макконепл, С. Л. Брю. - М.: Республика, 1992. - 388 с.

15. Малий І. Й. Іноземні інвестиції. Зарубіжний досвід стимулювання. Шляхи залучення в економіку. [Текст] / .- К.: НДФІ, 1999. - 43 с.

16. Маркс К. Капитал [Текст] / К. Маркс. - М.: Политиздат, 1988. - Т. 1. - 891 с.

17. Мертенс О. Інвестиційні рішення. Реструктуризація підприємства [Текст] / О. Мертенс. - Київ: Міжнародний інститут бізнесу, 2001. - 43 с.

18. Нестерчук Ю. О. Розвиток капіталізації сільськогосподарських підприємств [Текст] : монографія / Ю. О. Нестерчук, Ю. В. Улянич. - Умань: Сочінський, 2013. - 204 с.

19. Нестерчук Ю. О. Основи формування ресурсного потенціалу підприємств АПК та підвищення рівня їх капіталізації [Текст] / Ю. О. Нестерчук, Ю. В. Улянич, Н. В. Бутко // Збірник наукових праць Уманського національного університету садівництва. - 2012. - Вип. 81(2). - С. 39-46.

20. Про інвестиційну діяльність від 18 вересня 1991 р. №1560-ЧІІ. Закон України [Текст] // ВВР. 1991. - № 47. - С. 646.

21. Современный экономический словарь [Текст] / Под ред. Б. А. Райзберга, Л. Ш. Лозовского, Е. Б. Стародубцевой. - М.: ИНФРА, 2005. - 478 с.

22. Фишер С. Экономист [Текст] / С. Фишер, Р. Дорнбуш, Р. Шмалензи. - М.: Дело ЛТД, 1995. - 864 c. 
23. Шарп У. Инвестиции [Текст] / У. Шарп, Г. Александер, Дж. Бэйли. - М.: Ифра-М, 2001. - 1028 с.

24. Friedman M. Price theory, a provisional text [Text] / Friedman Milton. - Chicago: Aldine Pub. Co., 1968.

\section{References}

1. Birman, G. \& Shmidt, S. (1997). Jekonomicheskij analiz investicionnyh proektov [Economic analysis of investment projects]. Moscow: JuNITI [in Russian].

2. Blank, I. A. (2001). Osnovy investicionnogo menedzhmenta [Fundamentals of Investment Management]. (Vols. 1-2; Vol.2). Kyiv: Jel'ga-N [in Russian].

3. Bodi, Je., Kejn, A. \& Markus, Dzh. (2002). Principy investicij [Principles of investment]. Moscow: Vil'jams [in Russian].

4. Varchenko, O. M. (2012). Biudzhetna pidtrymka iak instrument zabezpechennia efektyvnosti derzhavnoi ahrarnoi polityky [Budget support as a tool for ensuring the effectiveness of the state agrarian policy]. Ekonomika ta upravlinnia APK - Economics and Management APC, 9, 5-9 [in Ukraine].

5. Gitman, L. Dzh. \& Dzhonk, M. D. (1997). Osnovy investirovanja [Basics of investing] . Moscow: Delo [in Russian].

6. Reverchuk, S.K., Reverchuk, N.J., Skomorovych, I.H.\& et al. (2001). Investology: the science of investing . S. K. Reverchuka (Ed.). Kyiv: Ataka [in Ukraine].

7. Kejns, Dzh. M. (1993). Obshhaja teorija zanjatosti, procenta i deneg: izbrannye proizvedenija [General theory of employment, interest and money: selected works]. Moscow: Jekonomika [in Russian].

8. Kyrychenko, O. A. \& Yerokhin, S. A. (2009). Investuvannia [Investment]. Kyiv: Znannia [in Ukraine].

9. Kolass, B. (1997). Upravlenie finansovoj dejatel'nost'ju predprijatija. Problemy, koncepcii i metody [Management of financial activity of the enterprise. Problems, concepts and methods]. Moscow: Finansy; JuNITI [in Russian].

10. Krysanov D.F. \& Varchenko, O.M. (2014). Investytsijno-innovatsijne zabezpechennia prodovol'choho kompleksu Ukrainy [Investment and innovation support of the food complex of Ukraine]. Aktual'ni problemy rozvytku ekonomiky rehionu - The actual problems of regional economy development, 10(1), 156-167 [in Ukraine].

11. Kuz'min, O.Ye., Kniaz', S. V., Tuvakova, N.V. \& Kuznietsova, A.Ya. (2003). Investytsijna ta innovatsijna diial'nist' [Investment and innovation activity]. L'viv: LBINBU [in Ukraine].

12. Lajko, O.I. (2013). Transformatsiia kontseptsii doslidzhennia investytsijnykh protsesiv [Transformation of the concept of research of investment processes]. Visnyk sotsial'no-ekonomichnykh doslidzhen' Socio-Economic Research Bulletin, 1, 220-229 [in Ukraine].

13. Lipsic, I. V. \& Kossov, V.V. (1996). Investicionnij proekt: ucheb. Posob [Investment project]. Moscow: BEK [in Russian].

14. Makkonepl, K. R. \& Brju, S.L. (1992). Jekonomiks: principy, problemy i politika [Economics: Principles, Problems and Politics]. (Vols. 1-3). Moscow: Respublika [in Russian].

15. Malyj, I.J. (1999). Inozemni investytsii. Zarubizhnyj dosvid stymuliuvannia. Shliakhy zaluchennia $v$ ekonomiku [Foreign investments. Foreign experience of stimulation. Ways of Engaging in the Economy.]. - Kyiv: NDFI [in Ukraine].

16. Marks, K. (1988). Kapital [Capital] . (Vol.1). Moscow: Politizdat [in Russian].

17. Mertens, O. (2001). Investytsijni rishennia. Restrukturyzatsiia pidpryiemstva [Investment decisions. Enterprise restructuring]. Kyiv: Mizhnarodnyj instytut biznesu [in Ukraine].

18. Nesterchuk, Yu.O. \& Ulianych, Yu.V. (2013). Rozvytok kapitalizatsii sil's'kohospodars'kykh pidpryiemstv [Development of capitalization of agricultural enterprises]. Uman': Sochins'kyj [in Ukraine].

19. Nesterchuk, Yu.O., Ulianych, Yu.V. \& Butko, N.V. (2012). Osnovy formuvannia resursnoho potentsialu pidpryiemstv APK ta pidvyschennia rivnia ikh kapitalizatsii [Basis of formation of resource potential of enterprises of agroindustrial complex and increase of their capitalization]. Zbirnyk naukovykh prats' Umans'koho natsional'noho universytetu sadivnytstva - Collected Works of Uman National University of Horticulture. 81(2), 39-46 [in Ukraine].

20. Pro investytsijnu diial'nist' vid 18 veresnia 1991 r. №1560-ChII. Zakon Ukrainy [On investment activity of September 18, 1991 №1560-ЧII. Law of Ukraine] . VVR, 47, 646 [in Ukraine].

21. Rajzberga, B.A., Lozovskogo, L.Sh., Starodubcevoj, E. B. (2005). Modern Economic Dictionary. Moscow: INFRA [in Russian].

22. Fisher S. Dornbush, R. \& Shmalenzi, R. (1995). Jekonomist [Economist]. Moscow: Delo LTD [in Russian].

23. Sharp, U., Aleksander, G. \& Bjejli, Dzh. (2001). Investicii. Moscow: Ifra-M [in Russian].

24. Friedman, Milton (1968). Friedman Milton Price theory, a provisional text, Chicago: Aldine Pub. Co. [in English]. 
Yuriy Gvozdev, postgraduate

Bila Tserkva National Agrarian University, Bila Tserkva, Ukraine

\section{Economic Essence and Value of Investments and Investment Activity of Business Entities}

The purpose of the study is to develop theoretical and methodological provisions for assessing the content of the concept of "investment activity" of business entities.

The study of the foreign and domestic theory of investment activity, the theoretical analysis of the methods of state regulation of the investment process made it possible to determine the range of issues relating to the instruments of the investment mechanism. They can be summarized as follows: means of knowledge and economic categories (as an instrument for understanding the functioning of the investment mechanism and the financial regulation of the activities of investment institutes, as well as the results and means of this knowledge) used in the theory and practice of studying the problems of improving the investment mechanism; institutes that carry out state financial regulation concerning the subjects of investment activity; principles and rules, functions, tasks and types of their production activities; methods and levers of the investment mechanism that are used in the process of state (administrative) and market (economic) regulation of the activity of investment institutes. The category as a broad concept reflects the most general and important properties, signs, connections and relations of objects, phenomena, processes, etc. Summarizing the above, we systematize the most important signs of investment: they can realize many goals - economic (in the form of income generation), management (improving the quality and competitiveness of products, optimizing costs, etc.), non-economic (social, environmental); contribute to the transformation of various resources of economic entities into alternative types of assets; ensure compliance with market laws of demand and supply for investment resources and services; accompanied by risks of capital investment, that is, the probability of expected results for investment purposes; are characterized by uncertainty of the timing of obtaining the achieved effect from the investment, as well as the dependence of the timing of obtaining benefits from the managerial decisions of the investor.

On the basis of the listed properties of investments it can be noted that this is a purposeful investment of capital that is not connected with current consumption and involves the transformation of resources of economic entities from one form to another in order to generate profit, as well as to achieve another economic and noneconomic long-term effect.

investment, capital investments, business entity, activity, financial resources

Е. О. Панченко, асп.

ДВНЗ «Київський національний економічний університет імені Вадима Гетьмана», м. Київ, Україна

\section{Механізми формування інтелектуального капіталу транснаціональних корпорацій}

У статті узагальнено сучасні практики формування та накопичення інтелектуального капіталу у транснаціональних корпораціях. Проаналізовано обсяги та динаміку фінансування транснаціональними корпораціями досліджень і розробок. Обгрунтовано, що існує два ключові механізми залучення інтелектуального капіталу - формування власного та залучення із зовнішніх джерел, які більшість транснаціональних корпорацій використовують для максимально ефективного накопичення інтелектуального капіталу та його використання. Висвітлено існуючі механізми спільної участі корпорацій в наукових дослідженнях, обсяги торгівлі результатами інтелектуальної діяльності.

інтелектуальний капітал, транснаціональна корпорація, дослідження і розробки (ДіР), роялті, патенти, ноу-хау

Е. О. Панченко, асп.

ГВУЗ «Киевский национальный экономический университет имени Вадима Гетьмана», г. Киев, Украина

() Е. О. Панченко, 2018 